\section{PD-061＼cjkstart自殺リスクのある中学生の被援助志 向性の検討}

○川本 静香

( ${ }^{1}$ 山梨大学)

キーワード：自殺リスク, 中学生, 被援助志向性

子どもの自殺が社会問題となる中，学校における自殺予防教育が推進 されている。自殺予防教育では, 子どもが自殺のリスクのある状態になっ た時に援助要請を行うことが重視される。しかし，自殺リスクのある状 態になったとき，子どもは援助要請ができる心理的状態にあるのだろう か。本研究では, 援助要請のなかでも被援助志向性に焦点を当て, 自殺 リスクのある中学生の被援助志向性の実態を検討することを目的とした。 102名の中学生（男子：55名, 女子：47名）を対象に調査を行った。抑う つ尺度（DSRS-C）のカットオフ值以上あるいは希死念虑項目に「いつも そうだ」と回答した者を「リスク群」とし，それ以外の者を「非リスク 群」とした。分析の結果, リスク群は16名, 非リスク群は86名となった。 各群の被援助志向性について, 田村・石隈（2001）の被援助志向性尺度 をもとに評価したところ，リスク群の方が有意に被援助志向性得点が低 いことが明らかとなり，自殺リスクのある中学生は他者に援助を求める 心理状態にはない可能性が示唆された。今後は, なぜ被援助志向性が低 いのかについて, 背景要因の検討が求められる。
PD-062

スキーマ療法におけるイメージ書き直 し実施中の患者の体験プロセスー1 事例の課題分析による予備的検討一

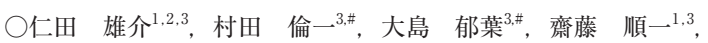

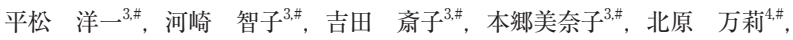
清水 栄司色, 熊野 宏昭 ${ }^{1}$

( ${ }^{1}$ 早稲田大学, ${ }^{2}$ 日本学術振興会特別研究員, ${ }^{3}$ 千葉大学子どものこころの 発達教育研究センター, ${ }^{4}$ 訪問看護ステーションステップ) キーワード：スキーマ療法，イメージ書き直し，課題分析

<背景>イメージ書き直し（IR）とは，不快なトラウマ的体験の記憶の イメージを安全な展開に書き直す技法であり, 認知行動療法やスキーマ 療法の中で使用される。IR のプロセスについては不明な点が多い。本研 究では, IR 実施中の患者の体験プロセスの予備モデルを作成した。

く方法>スキーマ療法を受けている慢性うつ病患者 1 名から同意を得て, 面接のビデオ録画を実施した。課題分析のプロトコルに従い，IR を実施 している面接 2 回分のビデオを分析した。本研究は千葉大学大学院医学 研究院倫理審查委員会の承認を経て実施された。

＜結果＞以下のプロセスが示された。(1)逆境体験に関する事実レベルで の語り，(2)重要他者への両価的感情に関する語り，(3)言葉にならない過 去の感情の探索と言語化, (4)重要他者への欲求と傷つき感情の今ここで の喚起, (5)欲求充足による複合的な感情の表出, (6)自分への思いやり, 安 心感の獲得。

<考察>傷つき感情が表出され, その後傷つき感情とポジティブ感情が 複合的に表出され, 最後にポジティブ感情が優勢になるというプロセス が示された。患者のこのような反応を, IR の順調な進行を示すプロセス 指標とすることが可能である。

連絡先 E-mail : yymy.yusuke.1212@asagi.waseda.jp

\section{PD-064＼cjkstart社交不安と表情に対する注意バイア ス，および注意の向け方に関するメ 夕認知的信念の関連性}

○上田 紋佳 ${ }^{1}$, 猪原 敬介

( ${ }^{1}$ 北里大学)

キーワード : 不安, ワーキングメモリ，修正版スタンバーグ課題

不安症を対象とした研究では, ワーキングメモリ（以下，WM）内で の課題に関連のない刺激の処理の制御能力に問題があることが示されて いる。しかしながら, 先行研究で用いられている課題では, 課題無関連 刺激が抑制されるプロセスについては詳細に検討することが困難である。 そこで, 本研究では, 課題に無関連な情報が抑制されていく過程を反映 することができるとされる修正版スタンバーグ課題（Oberauer, 2001）を 用いることとした。

不安症の症状から, 高不安者は不要となった情報をWM 内から排除す ることが困難であることが考えられる。そこで，本研究では，(1)高不安 者は時間経過に伴い不要となった情報が WM から排除されにくい, (2) WM 外へ排除された後も，活性化が保持され続けるかどうかを検討した。

実験の結果，仮説(1) は支持されなかった。ただし，本研究で用いた刺 激は感情価の操作を行わなかったため, 今後は刺激の感情価を操作する 必要があるだろう。仮説 (2) は有意傾向ではあるが, 特性不安が高いほど, 課題無関連刺激が WM 外へ排除された後の活性化が保持されやすい傾向 がみられた。一方，抑うつが高いほど，活性化が保持されにくいという 逆の結果が得られた。

連絡先 E-mail : aya.monka@gmail.com
○南出 歩美 ${ }^{1}$, 富田 望1, 武井 友紀 ${ }^{1}$, 亀谷知麻記1,*, 熊野 宏昭 ${ }^{1}$ (早稲田大学)

キーワード：社交不安，注意バイアス，メ夕認知的信念

\section{【背景】}

社交不安者にみられる一特徴に, 注意バイアス $(\mathrm{AB})$ がある。メ夕 認知療法では, $\mathrm{AB}$ を制御する要因として $\mathrm{AB}$ に関するメ夕認知的信念 （MCB）を想定しているが，これらの関連性を実証的に示した研究は少 ない。そこで，質問紙と認知課題を用いて，社交不安と $\mathrm{AB}, \mathrm{MCB}$ の関 連性を検討した。

【方法】

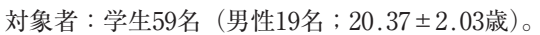
測定指標

（a）Liebowitz Social Anxiety Scale 日本語版（朝倉他，2002）：社交 不安。

(b) 注意の向け方に関するメ夕認知的信念尺度（富田他, 印刷中)： $\mathrm{AB}$ の有用性に関する $\mathrm{MCB}(\mathrm{PMCB})$ と, 制御不能性に関する $\mathrm{MCB}(\mathrm{NMCB}) 。$

(c) ドット・プローブ課題：表情に対する自動的／統制的 $\mathrm{AB}$ 。

【結果と考察】

社交不安と怒り顔への統制的 $\mathrm{AB}$, 社交不安と $\mathrm{NMCB}$, 怒り顔への統 制的 $\mathrm{AB}$ と $\mathrm{NMCB}$ との間に、いずれも有意な弱い正の相関が示された。 その他の変数間では, 有意な相関は示されなかった。上記の結果から, 社 交不安に関与しているのは怒り顔への統制的 $\mathrm{AB}$ であり, 注意の制御不 能感が社交不安や怒り顔への統制的 $A B$ と関連していることが示された。 